Research Article

\title{
Perception and behavior of urban women regarding fertility: a cross sectional study
}

\author{
Suneel Kumar Kaushal*, Meenal Kaushal, Gyan Prakash, Sunil Kumar Misra
}

Department of SPM, S. N. Medical College Agra, Uttar Pradesh, India

Received: 17 April 2016

Revised: 23 April 2016

Accepted: 24 May 2016

\section{*Correspondence:}

Dr. Suneel Kumar Kaushal,

E-mail: dr.suneel31@ rediffmail.com

Copyright: (C) the author(s), publisher and licensee Medip Academy. This is an open-access article distributed under the terms of the Creative Commons Attribution Non-Commercial License, which permits unrestricted noncommercial use, distribution, and reproduction in any medium, provided the original work is properly cited.

\begin{abstract}
Background: Fertility is only way for biological replacement of human being in order to continue its existence on earth. The fertility behavior of any population is influenced by various factors. Objective of the study is to study the fertility perception and behavior among urban women in Agra and understand the social factors on perception of women regarding fertility behavior among study group women.

Methods: Community based, Cross-sectional study was done among 280 married women of reproductive age group residing in Agra City, using a standardized questionnaire to assess their fertility perception and behavior.

Results: Mean age of marriage was 19.01 years. About $70 \%$ of women married before the age of 20. Mean gap between marriage and first child was 1.57 years. The mean least birth interval was 1.61 years. Less than one third of women desired for more than two children. Level of education, transition from lower to high SE status, significantly shifts the preferred family size.

Conclusion: Majority of women considered appropriate age of marriage 18 year and above, gap between marriage and first child two years and above, wishes for two child norm. However, two third had confessed the necessity of mail child. Level of education and working status of women had positively effect.
\end{abstract}

Keywords: Fertility behavior, Age of marriage, Birth interval

\section{INTRODUCTION}

Fertility is meant the actual bearing of children. Fertility is only way for biological replacement of human being in order to continue its existence on earth. Of the three main aspect of demography are fertility, migration and mortality, in which the fertility always occupancies in central position in population studies. The fertility rate of any population is always influenced by various factors and the degree of these factors on fertility may differ from community to community. Age at marriage, gap between first child and marriage, desired number of children, desire of necessity of male child and education, occupation, socio-economic status are some factors influencing the fertility behavior and their perception. ${ }^{1,2}$

The preferences of son ultimately affect the demographic behavior; either reduces sex ratio or increase the total fertility rate to get more sons.

\section{METHODS}

This community based, cross sectional study was conducted in Agra city, among the women of reproductive age group residing in urban Agra. The world renowned city Agra situated in the South- West region of Uttar Pradesh state of India. The population of the district 
is 4.3 million (Census 2011). Married Women of age 1545 years were taken as study subjects. Those women who are not giving consent, infertile, living without her husband and divorced were not included.

Before commencing the study, the institutional ethical clearance was taken. The study was carried out during the period of 18 months i.e. from May 2013 to August 2014. For valid inferences, a minimum sample size was calculated using the formula (3) given below:

$$
\mathrm{n}=\mathrm{Z}_{\alpha / 2}^{2} \frac{\mathrm{PQ}}{\mathrm{L}^{2}}
$$

The prevalence of couple protection rate $41.2 \%$ for modern methods for urban Agra is assumed for sample size calculation. ${ }^{4}$ The calculated sample size at $5 \%$ level of significance $(=1.96)$ and $15 \%$ allowable error is 253.7 . Rounding up the sample size up to 280 with consideration of $10 \%$ dropout.

A simple random sampling technique was applied here to reach the desired sampling unit from a randomly chosen ward (Shahganj) from 90 municipal wards of Agra city. A random direction was taken for selection of first house thereafter house to house visits were made till the sample size was completed. If a house had more than one study subjects, the first respondent only was picked from that household. Before starting the interview, the purpose of study was explained and motivated to participate and reveal the correct information. Informed written consent was taken from the participants, in their local language (Hindi) and their confidentiality was maintained. The questions focused in, age, duration of marriage, religion, type of family, years of formal education, socio economic status and age at marriage, necessity of male child, desired family size and desired birth interval. Based on objectives, the collected data were analyzed and valid inference was drowning by Z-Test and Chi-Square Test. Data analysis was done using SPSS-20.

\section{RESULTS}

Based on Table 1, it is observed that the mean age of marriage was 19.01 years. About $70 \%$ of women married before the age of 20 , even $31.8 \%$ married before the age of 18. However, none of the respondent opined for marriage before 18 years majority. $82.9 \%$ considered appropriate age for marriage 18-23 years and the husband opined for age of marriage $>20$ years (77.6\%). A highly significant difference was observed between the actual age at marriage and the appropriate age of marriage $(\mathrm{z}=10.6 ; \mathrm{p}<0.001$ at $\alpha=5 \%$ ).

Table 2 depicts that the mean gap between marriage and first child was 1.57 years. Though in accordance $(\mathrm{z}=0.864 ; \mathrm{p}<0.05$ at $\alpha=5 \%)$ with the mean gap of 1.64 years, as considered appropriate by husband, but significantly varied $(z=6.89 ; p<0.001$ at $\alpha=5 \%)$ from that desired by the respondents. From 280 respondents, 22 did not have a live child till the date of interview, of remaining 258, most of them conceived and have a baby within two years of their marriage.

Table 1: Age at marriage of respondent.

\begin{tabular}{|llll|}
\hline $\begin{array}{l}\text { Age at marriage } \\
\text { (in years) }\end{array}$ & Actual number $(\%)$ & \multicolumn{3}{l|}{ Age for marriage considered appropriate by } \\
\hline$<18$ & $89(31.8 \%)$ & Herself $\mathrm{n}(\%)$ & Husband $\mathrm{n}(\%)$ \\
\hline $18-20$ & $108(38.6)$ & 0 & 0 \\
\hline $21-23$ & $55(19.6 \%)$ & $133(47.5 \%)$ & $63(22.4)$ \\
\hline$>24$ & $28(10 \%)$ & $99(35.4 \%)$ & $113(40.4 \%)$ \\
\hline Average Age & 19.01 & $48(17.1 \%)$ & $104(37.2 \%)$ \\
\hline $95 \%$ CI & 18.67 to 19.35 Years & 21.19 & 21.8 \\
\hline SD & $3.5 \mathrm{yrs}$ & 20.85 to 21.54 Years & 21.46 to 22.19 Years \\
\hline
\end{tabular}

Table 2: Gap between marriage and first child.

\begin{tabular}{|c|c|c|c|}
\hline \multirow{2}{*}{$\begin{array}{l}\text { Gap between marriage } \\
\text { and first child (in years) }\end{array}$} & \multirow{2}{*}{$\begin{array}{l}\text { Actual Gap } \\
\text { n (\%) }\end{array}$} & \multicolumn{2}{|c|}{ Gap considered appropriate by } \\
\hline & & Herself $\quad \mathrm{n}(\%)$ & Husband \\
\hline$<1$ & $24(9.3 \%)$ & 0 & 0 \\
\hline $1-2$ & $31(50.8 \%)$ & $64(22.9 \%)$ & $148(52.9 \%)$ \\
\hline $2-3$ & $66(25.6 \%)$ & $118(42.1 \%)$ & $98(35.0 \%)$ \\
\hline$>=3$ & $37(14.3 \%)$ & $98(35.0 \%)$ & $34(12.1 \%)$ \\
\hline Total & 258 & 280 & 280 \\
\hline Average Ages & 1.57 Years & 2.20 Years & 1.64 Years \\
\hline $95 \% \mathrm{CI}$ & 1.44 to 1.69 Years & 2.08 to 2.33 Years & 1.52 to 1.77 Years \\
\hline SD & 1.21 Years & 0.91 Years & 0.83 Years \\
\hline
\end{tabular}


Table 3: Least birth interval.

\begin{tabular}{|c|c|c|c|}
\hline \multirow{2}{*}{$\begin{array}{l}\text { Birth interval (in } \\
\text { years) }\end{array}$} & \multirow{2}{*}{$\begin{array}{l}\text { Actual least birth interval } \\
\mathbf{n}(\%)\end{array}$} & \multicolumn{2}{|c|}{ Birth interval considered appropriate by } \\
\hline & & $\begin{array}{l}\text { Respondents } \\
\mathrm{n}(\%)\end{array}$ & $\begin{array}{l}\text { Husband } \\
\mathrm{n}(\%)\end{array}$ \\
\hline$<=1$ & $100(57.4 \%)$ & $2(0.7 \%)$ & $5(1.8 \%)$ \\
\hline $1-2$ & $50(28.7 \%)$ & $41(14.6 \%)$ & $30(10.7 \%)$ \\
\hline $2-3$ & $18(10.3 \%)$ & $132(47.1 \%)$ & $55(19.6 \%)$ \\
\hline$>3$ & $6(3.4 \%)$ & $102(36.4 \%)$ & $180(64.3 \%)$ \\
\hline Don't know & - & $3(1.2 \%)$ & $10(3.6 \%)$ \\
\hline Total & $174 *$ & 280 & 280 \\
\hline Average Interval & 1.61 Years & 3.53 Years & 3.82 Years \\
\hline $95 \% \mathrm{CI}$ & 1.46 to 1.76 Years & 3.38 to 3.68 Years & 3.69 to 3.94 Years \\
\hline $\mathrm{SD}$ & 0.98 Years & 1.26 Years & 1.04 Years \\
\hline
\end{tabular}

*126 women, not having two children, were excluded.

Table 3 represents the least birth interval between two children. The average least birth interval observed as 1.61 years and this was highly statistically significant $(\mathrm{z}=17.0$; $p<0.001$ at $\alpha=5 \%$ and $z=22.0 ; p<0.001$ at $\alpha=5 \%)$ from the mean gap considered appropriate by the respondents
(3.53 years) and their husbands (3.82 years). Nearly half of respondents wished to gap between two children two years while their husbands opined for more than three years.

Table 4: Number of children.

\begin{tabular}{|c|c|c|c|c|}
\hline Number of children & Appropr & nber of child & & Total n (\%) \\
\hline & $1 \mathrm{n}(\%)$ & $2 \mathrm{n}(\%)$ & $\mathrm{n}(\%)$ & \\
\hline 0 & 0 & $22(100 \%)$ & 0 & $22(7.9 \%)$ \\
\hline 1 & $8(9.5 \%)$ & $58(69.1 \%)$ & $18(21.3 \%)$ & $84(30.0 \%)$ \\
\hline 2 & 0 & $55(68.7 \%)$ & $25(31.3 \%)$ & $80(28.6 \%)$ \\
\hline$>=3$ & 0 & $50(53.2 \%)$ & $44(46.8 \%)$ & $94(33.5 \%)$ \\
\hline Total & $8(2.9 \%)$ & $185(66.0 \%)$ & $87(31.1 \%)$ & $94(33.5 \%)$ \\
\hline Fisher Exact test & 41.9 & d.f. $=6$ & $\mathrm{P}<0.001$ & \\
\hline
\end{tabular}

From Table 4, we observed that, only 22 did not have a child while 94 had three or more live children from 280 respondents. Only less than one third of women desired for more than two children and this difference found statistically significant.

Table 5 states the necessity of the male child. Two third had confessed that the need of a male child, stating that despite attaining the desired family size, a couple must have a male child. This pattern extended both across those already having a male child and those not having one.

Majority among Hindus considered two child while Muslim more than two child considered appropriate and this difference in opinion was statistically significant. Level of education positively effect on two child norm. Majority of women considered two child norm, housewife (63.4\%) and Income generating activity (IGA) outside home $78.8 \%$ which is statistically significant.

Transition from lower to high Socio-Economic (SE) status, significantly shifts the preferred family size (Table $6)$.

Table 5: Necessity of male child.

\begin{tabular}{|llll|}
\hline Necessity & $\begin{array}{l}\text { Actual presence of male } \\
\text { child }\end{array}$ & Total n (\%) \\
\hline & $\begin{array}{l}\text { Yes } \mathrm{n} \\
(\%)\end{array}$ & $\begin{array}{l}\text { No } \mathrm{n} \\
(\%)\end{array}$ & \\
\hline Yes & 136 & 46 & 182 \\
& $(65.7 \%)$ & $(64.8 \%)$ & $(65.0 \%)$ \\
\hline No & 74 & 24 & 98 \\
& $(34.3 \%)$ & $(35.2 \%)$ & $(35.0 \%)$ \\
\hline Total & 210 & 70 & 280 \\
& $(100.0 \%)$ & $(100.0 \%)$ & \\
\hline Chi-square & 0.21 & $\mathrm{df}=1$ & $\mathrm{p}>0.05$ \\
\hline
\end{tabular}


Table 6: No of children appropriate and social factors.

\begin{tabular}{|c|c|c|c|c|c|}
\hline \multicolumn{6}{|c|}{ No. of Children considered appropriate by respondents } \\
\hline Religion & 1 & 2 & 3 & $>=4$ & Total \\
\hline Hindu & $8(4.2 \%)$ & 139(72.4\%) & $43(22.4 \%)$ & $2(1.0 \%)$ & 192 \\
\hline Muslim & 0 & $30(41.7 \%)$ & $28(38.9 \%)$ & $14(19.4 \%)$ & 72 \\
\hline Others & 0 & $16(100.0 \%)$ & 0 & 0 & 16 \\
\hline \multicolumn{6}{|c|}{ Fischer Test $=56.0, \mathrm{df}=6, \mathrm{p}<0.001$} \\
\hline \multicolumn{6}{|c|}{ Years of formal education } \\
\hline Illiterate & 0 & $46(51.7 \%)$ & $35(39.3 \%)$ & $8(9.0 \%)$ & 89 \\
\hline$<7$ & 0 & $21(55.3 \%)$ & $13(34.2 \%)$ & $4(10.5 \%)$ & 38 \\
\hline $7-9$ & $2(4.5 \%)$ & $36(81.8 \%)$ & $6(13.6 \%)$ & 0 & 44 \\
\hline $9-11$ & 0 & $24(58.5 \%)$ & $15(36.6 \%)$ & $2(4.9 \%)$ & 41 \\
\hline$>11$ & $6(8.8 \%)$ & $58(85.3 \%)$ & $2(2.9 \%)$ & $2(4.9 \%)$ & 68 \\
\hline \multicolumn{6}{|c|}{ Fischer Test $=55.6, \mathrm{df}=12, \mathrm{p}<0.001$} \\
\hline \multicolumn{6}{|c|}{ Occupation } \\
\hline Housewife & $8(3.7 \%)$ & 137(63.4\%) & $57(26.4 \%)$ & $14(6.5 \%)$ & 216 \\
\hline IGA at home & 0 & $34(73 \%)$ & $10(21.7 \%)$ & $2.43 \%)$ & 46 \\
\hline IGA outside home & 0 & $14(77.8 \%)$ & $4(22.2 \%)$ & 0 & 18 \\
\hline \multicolumn{6}{|c|}{ Fischer Test $=5.2, \mathrm{df}=6, \mathrm{p}<0.05$} \\
\hline SE status & 1 & 2 & 3 & $>=4$ & Total \\
\hline SE Class I & 0 & $4(100.0 \%)$ & 0 & 0 & 4 \\
\hline SE Class II & $8(8.3 \%)$ & $82(85.4 \%)$ & $6(6.3 \%)$ & 0 & 96 \\
\hline SE Class III & 0 & $32(51.6 \%)$ & $24(38.7 \%)$ & $6(9.7 \%)$ & 62 \\
\hline SE Class IV \& V & 0 & $67(56.8 \%)$ & $41(34.7 \%)$ & $10(8.5 \%)$ & 118 \\
\hline \multicolumn{6}{|c|}{ Fischer test $=57.3, \mathrm{df}=9, \mathrm{p}<0.001$} \\
\hline Total & $8(2.9 \%)$ & $185(66.1 \%)$ & $71(25.3 \%)$ & $16(5.7 \%)$ & 280 \\
\hline
\end{tabular}

\section{DISCUSSION}

Age at marriage is considered approximate determinant of fertility. It has a profound impact on childbearing, because a woman who marry early have a longer period of exposure to pregnancy. In present study the median age at marriage was estimated as 19 years which is comparable to that state by NFHS-III (2005-2006) for urban women (18.8 years) and by the DLHS-III (20072008 ) for Uttar Pradesh (18.4 years). ${ }^{2}$ It is observed that, $31.8 \%$ of women married before they attaining the age of $18 .^{5}$

Similar finding was reported by NFHS-III (2005-2006) and DLHS-III (2007-2008) for urban areas of Uttar Pradesh and MLE Agra 2011. ${ }^{6}$ Most of women (82.9\%) considered the appropriate age for marriage which is 1823 years, while none considered marriage below 18 years as ideal. DLHS-III (2007-08) stated a higher proportion $(97.9 \%)$ MWRA reported 18 years or more as girl's ideal age of marriage.

The present study found that $60.1 \%$ of the women had delivered their first child within 2 years of marriage, implying conception within 15 months of consummation. Pradhan found a much higher proportion $(78 \%)$ of the women, had conceived within the first years of their marriage in rural Orissa. ${ }^{7}$ The variation may be a subtle pointer to differing socio-cultural settings (the present study was among urban women of western uttar pradesh, a comparatively advanced setting than the rural part of eastern india); or it may be a reflection of the temporal changes in the socio-cultural milieu of the gradually changing India (as the present study was conducted more than six years after the one conducted in rural orissa.). The present study found that only $22.9 \%$ women considered it appropriated to have the first child before completing 2 years of marriage.

Jha reported a higher proportion of the women (36.5\%) who considered an early child (before two years of marriage) as ideal from Rural Kolkata. ${ }^{8}$ Though the mean gap between marriage and first child was 1.57 years, it was significantly smaller than the mean gap considered appropriate by the women (2.2 Years); but was in accordance to the mean gap considered ideal by men (1.64 Years) This indirectly reflects that the women eventually complied with their husbands considered appropriate. More than half (52.9\%) of the respondent's husbands had stated that the first child should be born before completing two years of marriage.

A much higher proportion $(78 \%)$ was recorded by Pradhan, perhaps due to the difference in the sociocultural milieu of the settings where the researches were conducted. ${ }^{6}$ Sort birth intervals may adversely affect a 
mother's health, with $150 \%$ increased risk of maternal death. (USAID ESD Country Profile India. ${ }^{9}$ Thus, the concept of Healthy Timing and Spacing of Pregnancies (HTSP) is being emphasized world over.

In the present study, a whopping $86.2 \%$ had, at least once, delivered within 2 years of the previous childbirth wherein $57.5 \%$ had the least birth interval of one year. In contract, NFHS-III (2005-06) and USAID ESD (India) Document reported far lesser proportions (39\% and $28 \%$ respectively) of births within 2 years of last childbirth. The dismal picture in the present study is perhaps, and attributed to the fact that least birth interval was considered for those respondents who have had more than two children, in contract to the NFHS-III (2005-06) and USAID ESD Report, where birth interval for the last child was accounted for. Majority $(83.5 \%)$ considered more than 2 years as the appropriate gap, wherein $47.1 \%$ believed 3 years was the ideal birth spacing.

The present data is in accordance with documented by Chaudhary that $54 \%$ considered 3 years as ideal interval. ${ }^{10}$ Though, a higher proportion of respondents $(36.4 \%)$ considered more than three years as an ideal birth interval, perhaps because of heightened emphasis by the mass campaigning, in the past year on raising the gap between marriage and first child. Similarly, MLE Agra Report had stated that $44.2 \%$ of the women had considered 3 years as the ideal birth interval while $35.6 \%$ of the women had considered more than 3 years as the ideal gap between two children. But, Jha documented had more $(23 \%)$ women in Rural Kolkata, had incorrect knowledge about spacing between subsequent pregnancies (> 3 years); perhaps indicating a sociocultural variation between the two research settings. ${ }^{8}$

Though in the present study, $83.9 \%$ of the respondent's husbands had stated three or more years as the appropriate gap, the MLE (Agra) Baseline Study stated that among men, fewer $(71.1 \%)$ had considered three or more years as appropriate interval. This variation may be due to the inclusion of non-slum dwellers, with a higher education and SE status in the present study. In the present study, $33.5 \%$ had more than three children, which was comparable with National NFHS-III (2005-06), which reported $39.8 \%$ had three or more children. While the mean number of living children in the present study was 2.26, NFHS-III (2005-06), reported this figure to be as high as 2.52 among MWRA, probably reflecting a higher mean number of children among the rural population. MLE reported a higher proportion (49.8\%) of the women with three or more children. This may be explained by the fact that the report included only the slum residents in urban Agra while the present study had also considered both slum and non-slum residents of Agra city.

In the present study, the mean ideal family size, according to the women and their husbands is 2.4 and 2.5 respectively. Islamuddin stated that the mean number of children considered appropriate by couple in Bangladesh was 2.2 , which is slightly lower than that in the present study. ${ }^{11}$ This may be the reflection of the global scenario, as the concept of small family norm is taking up the notice. But according to NFHS-III UP Report (2005-06), the ideal family size for ever-married women and men was slightly more (2.6 and 2.7 children respectively). This variation could be either due to inclusion of rural areas or it may be a pointer to the progressive trend over past 8 years, reflecting that the desired family size has plummeted since the survey was last conducted. The present study also found that the majority $(66.1 \%)$ of the respondents considered two children as the ideal number while $25.4 \%$ had narrated that the ideal number of children per couple is three. Similarly, NFHS-III (200506), Chaudhary and MLE (Agra) 2011 stated that about two-third $(69 \%, 68.8 \%$ and $60.4 \%)$ of women considered one or two children, be the ideal number of children. ${ }^{10}$

About the question of size of ideal family size, is sometimes criticized on the ground that women tend to adjust their ideal family size upward as the number of their living children increases, in process of rationalizing previously unwanted children as wanted. However, it is evident form the present study that this is not the case for many women, as $53.2 \%$ of those who had more than three children stated two children as the ideal number. Similarly, NFHS-III (2005-06) found that among women with three children, $56.7 \%$ considered two or lesser as ideal. It is evident that a substantial proportion has more than the number of children they considered appropriate and this may serve as an important indicator of unwanted fertility. In the present study, half $(51.4 \%)$ of male respondents stated two or lesser as ideal number of children, while $45.0 \%$ husbands beloved that three children per couple is the appropriate number of children. Similarly, NFHS-III (2005-06) stated that 90\% men considered two, three or even lesser number as appropriate. MLE (Agra), 2011 also reported a comparable data of $52.6 \%$ men who stated two was the ideal number of children and $38.8 \%$ men believed three or more as the appropriate number. Whereas Jha documented a different trend in Rural Kolkata. ${ }^{8}$ The reported that, $22.3 \%$ of respondents had narrated a preference to have more than three children as against $5.7 \%$ of such respondents in the present study. This wide difference could either be a reflection Urban-Rural variation of fertility preferences or the effect of varying religious composition of the study populations (Present study consists of $25.7 \%$ Muslim respondents while his study had $32.9 \%$ Muslims).

The appropriate number of male and female children according to the women is obtained 1.42 and 0.99 respectively. NFHS-III (2005-06), reported that the average ideal family according to women consisted of 1.1 and 0.8 male and female children respectively. $65 \%$ respondents stated that the need of a male child to label the family complete. Chaudhary also stated that the desire of a male child had compelled as many as $59.5 \%$ of the 
women to have more children than what they had considered appropriate. ${ }^{10}$ While in the present study, $67.1 \%$ considered one male child as ideal, $32.9 \%$ stated that more than one male child is required in the family to consider it as ideal. Whereas NFHS-III (2005-06) stated a lesser proportion $(77 \%)$ of the women wanted at least one son among their children. This variation could be due to the inclusion of states with matriarchal dominance in the National NFHS-III Report (2005-06), whereas the present study was limited within a city of Uttar Pradesh, which is primarily a male dominate society.

\section{CONCLUSION}

Majority of women considered appropriate age of marriage 18 year and above, gap between marriage and first child two years and above, wishes for two child norm. However, two third had confessed the necessity of mail child. Level of education and working status of women had positively effect.

Funding: No funding sources

Conflict of interest: None declared

Ethical approval: The study was approved by the Institutional Ethics Committee

\section{REFERENCES}

1. Park K, Park S. Textbook of preventive and social medicine:demography and family planning. $23^{\text {rd }}$ ed. M/s Banarsidas Bhanot publisher; 2015:487.

2. NFHS National Report (2005-06). Available at: http://www.rchiips.org/nfhs/report.shtml.

3. Bartlett JE, Joe W. Higgins KCC. Organizational research: determining appropriate sample size in survey research available at: http://www.google.co.in/url?sa=t\&rct=j\&q=\&esrc= $\mathrm{s} \&$ source $=$ web $\& \mathrm{~cd}=1 \& \mathrm{cad}=$ rja $\&$ uact $=8 \& \mathrm{ved}=0 \mathrm{CB}$ 0QFjAA\&url=http $\% 3 \mathrm{~A} \% 2 \mathrm{~F} \% 2 \mathrm{Fchuang}$.epage.au.e du.tw\%2Fezfiles\%2F168\%2F1168\%2Fattach\%2F2
0\%2Fpta_39317_692177_91008.pdf\&ei=Q0q_VO2 wHM6B8QXQm4HQCw\&usg=AFQjCNFfbv4CZl Agq34LA0xgQLzokrL7gA\&sig2=RI9_jtSuTzhwW O3Bv9bSgQ\&bvm=bv.83829542,d.dGc. Accessed on Jan 21, 2015.

4. Annual Health Survey 2011 Report. Available at: http://mohfw.nic.in/WriteReadData/1892s/69601445 09Annual\%20Report\%20to\%20the\%20People\%20o n\%20Health.pdf.

5. DLHS-III (2007-2008). Available at: http://www.jsk.gov.in/dlhs3/UPradesh.pdf.

6. MLE. Baseline survey report of agra city, march 2011. Available at: www.uhi-india.org.in/MLEdata/Agra-report-April.pdf.

7. Pradhan MR. Unintended pregnancy among rural young women: does gender role matter? The Indian Journal of Family Welfare. 2008;54(1).

8. Jha SN, Bau B, Haldar A, Dasgupta U. A study on fertility perception: an experience from West Bengal, India. Int J Prev Med. 2014;5(1):16-20.

9. USAID, ESD Participatory Assessment: Report No.09-001-178. Available at: www.GHTechproject.com/resourse.aspx.

10. Chaudhary V. Study of perception and practices related to contraceptives among married women of reproductive age group of urban slums of Agra. Unpublished thesis, submitted for award of MD Community Medicine, at Dr. B. R. Ambedkar University Agra, 2009.

11. Islamuddin M, Bhuyan KC, Islam SS. Determinants of desired family size and children ever born in Bangladesh. The Indian Journal of Family Welfare. 2011;57(2):39-47.

Cite this article as: Kaushal SK, Kaushal M, Prakash G, Misra SK. Perception and behavior of urban women regarding fertility: a cross sectional study. Int $\mathbf{J}$ Community Med Public Health 2016;3:1573-8. 